\title{
ACADEMIC ACHIEVEMENT AND TIME CONCEPT OF THE LEARNER
}

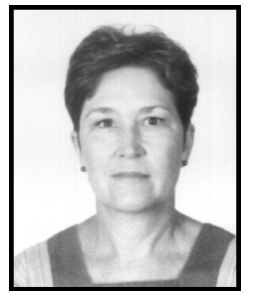

RC Grobler

BSc.; DEd.; NSED

Lecturer: Dept Education Sciences

Rand Afrikaans University

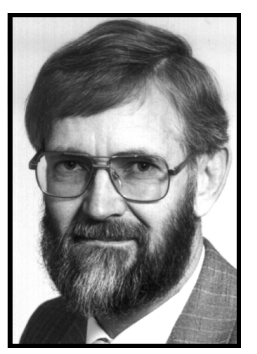

\section{CPH Myburgh}

BSc. Hons.; MCom.; DEd.; HED

Professor, Dept Education Sciences

Rand Afrikaans University

\section{ABSTRACT}

The time concept and academic achievement of a group of high school learners were investigated and the results are described in this article. The focus was on: the differences between the time concept of high achievers and the time concept of low achievers; the differences in the time concept of high achievers and low achievers according to their mother tongue; and the educational implications of the findings with respect to the learners. These learners' time concept was measured by the application of a structured questionnaire. A group of 1436 learners were involved in this research. Their academic achievements were rated on a scale of 0 to 100. Two groups were identified: high achievers and low achievers. A difference was found in the time concept of these two groups. Furthermore, the learners were divided into their various mother tongue groups that would give an indication of their time concept with which they grew up. The Afrikaans- and English speaking high achievers were more future directed, more conscientious in their time management, experience less anxiety about the future, were less focussed on the present and were more content with the present and the past than the low achievers. Among the learners with an African language no statistical significant difference were found between the high and low achievers, only 15,3\% of them were high achievers. The learners with an African language need to be assisted to develop a linear and integrated time concept. Only then these learners will be able to actualise their full potential.

\section{OPSOMMING}

Die tydkonsep en akademiese prestasie van 'n groep hoërskool leerders is ondersoek en die resultate is beskryf in hierdie artikel. Die fokus was op: die verskille tussen die tydkonsep van hoë presteerders en die tydkonsep van lae presteerders; die verskille in die tydkonsep van hoë en lae presteerders verdeel volgens hulle moedertaal; en die opvoedkundige implikasies van bevindings vir leerders. Hierdie leerders se tydkonsep was gemeet deur die toepassing van 'n gestruktureerde vraelys. 'n Groep van 1436 leerders is in hierdie ondersoek betrek. Hulle akademiese prestasies is gegradeer van 0 tot 100. Twee groepe is geïdentifiseer: hoë presteerders en lae presteerders. ' $n$ Verskil is gevind in die tydkonsep van hierdie twee groepe. Verder is die leerders volgens hulle onderskeie moedertaalgroepe verdeel wat 'n aanduiding sou gee van die tydkonsep waarmee hulle grootgeword het. Die Afrikaans- en Engelssprekende hö̈ presteerders is meer toekomsgerig, meer konsensieus in hulle tydbestuur, ervaar minder toekomsangs, is minder op die hede gerig en is meer 
tevrede met die hede en verlede as die lae presteerders. By die Afrikataalleerders is geen statisties beduidende verskil gevind tussen die hoë en lae presteerders nie, slegs 15,3\% van hulle is hoë presteerders. Die leerders met 'n Afrikataal moet begelei word om 'n lineêr en gë̈ntegreerde tydkonsep te ontwikkel. Slegs dan sal hierdie leerders by magte wees om hulle volle potensiaal te aktualiseer.

\section{INTRODUCTION}

It has become clear that not only do the learners in our schools need to be given knowledge, they need to be given cognitive skills (thinking skills) which will enable them to cope with new, increasingly more complex or difficult problems in a satisfactory manner. According to Kaplan (in Marais, 1999:1) schools must therefore "educate for mental health". One of these more complex problems may be seen as the clamant need for higher academic achievements that make greater demands, both on educators (parents and teachers) and learners (Grobler, Myburgh \& Kok, 1998:1). It has become vital for the educator to try and find answers to how he/she can assist learners towards higher academic achievement, as this seems to be of utmost importance for the development of a positive self-concept of learners. If a learner does not achieve well at school, his/her affective development, which is emphasised by the mental health movement (Marais, 1999:2), may be hampered.

There are various factors that could play a role in academic achievement. Myburgh, Grobler and Niehaus (1999:165-178) found in their research that some of the predictors of scholastic achievement include IQ, self-concept, time concept and background characteristics. In reference to time concept one important fact may be that the timely completion of assignments promotes the attainment of scholastic and cognitive skills and capabilities. The timely addressing of assignments that can be related to effective time management (Gmeiner \& Poggenpoel, 1997:10) is one of the aspects of the ways that one can attend to in his/her everyday management of life. According to Ben-Baruch, Myburgh, Wiid and Anderssen (1990:62) time and the conceptions thereof are “... inseparably associated with achievement and success". This statement encapsulates the relationship between mental health, time management, the experience of success and a healthy self-concept.

\section{PROBLEM STATEMENT}

Due to political and social changes and the influence of these changes on education structures, learners in South Africa are placing new and even higher demands on academic achievement. The need for higher achievement is also demanded by the modern technological society. These demands make it more problematic for the learners to cope with the expectations, and if they do not develop some capacity to live with these stressful situations, it might have an indirect effect on the individual learner's mental health. The problem is that the majority of South African learners are not sufficiently equipped for academic achievements. In the introductory paragraph it was quoted that time concept is associated with achievement and success. What then is an appropriate time concept that may support academic achievement and mental health and who are the learners that are not sufficiently equipped for academic achievement? Against this background the problems addressed in this research project were demarcated as:

How does the time concept of learners with a high average in academic achievement (high achievers) differ from the time concept of learners with a low average in academic achievement (low achievers)? How does the time concept of high achievers and low achievers differ according to their mother tongue?

What are the educational implications of the above for the learners? 


\section{AIM OF THE ARTICLE}

The time concept of a group of high school learners was investigated. It is the aim of this article to describe the:

- differences between the time concept of high achievers and the time concept of low achievers;

- differences in the time concept of high achievers and low achievers according to their mother tongue; and

- $\quad$ educational implications of the findings with respect to the learners.

\section{THEORETICAL PERSPECTIVES}

\section{Time concept in mental health perspective}

Jaques (1982:15) has distinguished two dimensions of time: chronological time and experiential time. Chronological time refers to the sequential characteristic of time that is measurable by chronometers or watches, in other words "watch time" or "calendar time" (Burgers, 1993:29). This refers to the time of events with a definite beginning, middle and end. This measurable characteristic of chronological time is of utmost importance to regulate society and relationships. An inevitable implication of chronological time is that time as such is divided into a past, a present and a future. From the past the human being is planning in the present for the future. Through this planning, meaning is attached to the future and he/ she thus directs him/herself towards the future. If a person experiences that he or she cannot cope or live up to offer self-set standards this might be an obstacle to his/her experience of mental health.

In contrast to chronological time, experiential time relates to the human being's intentions, needs and aims (Jaques, 1982:14-16). Concerning the experiential dimension of time, Ben-Baruch (1985:25-34) has distinguished three basic ways of viewing time:

Time is cyclic - i.e. rhythmic and repetitive; thus it is not a scarce resource and there is no reason why there should be any haste because it is plentiful. A productive inclination in this case is absent to a large degree and it is expected that scholastic achievement and the importance thereof will not enjoy a high priority.

- Time is linear and infinite (unlimited or endless) - i.e. time is experienced as flowing constantly in one direction; the human being must plan to obtain certain results within an irreversible, though prolonged and extensive period. In this case it is expected that scholastic achievement and striving towards it will enjoy higher prominence, but as time is plentiful the importance of, and a productive inclination, will still be largely absent.

Time is linear and limited - i.e. time is measured and restricted, the human being involved is placed under the pressure of time limits to meet the demands set to complete tasks and assignments. In this case it is expected that academic achievement and a productive inclination will be highly emphasised.

These three views of time are not necessarily mutually exclusive, although one of these modes might be more prominent at a specific point in time. In other situations one of the other two modes of experiencing time might be more dominant. It should be clear that the dominant way of viewing time in a specific situation will definitely play a role in the way in which the individual experiences and treats the demands of time constraints.

A learner is "taught" in the home and especially in school to organise time and utilise it purposefully, in other words, to be bounded and restricted by time. This can happen intentionally or unintentionally. According to Ben-Baruch (1985:32), the school purposefully acquaints the learner with the linear and limited time mode. Achievement at school and also later in life can be attributed to this time 
concept as it is characteristic of the technological society in that it sets the pace for the economy. Fraisse (in Gormann \& Wessman, 1977:32) states that the complete development of the time concept only occurs in the late adolescent years.

\section{Time concept and culture}

The differences in time concept between cultural groups are prominent when the modern, Western, technological oriented perspective is compared with the time perspective of the more traditional oriented people (Burgers, 1993:36). In the modern, Western, technological community it is believed that 'time is money' while traditional African cultures are not concerned about time because 'he is not a slave of time' (Mbiti, 1967:34).

Different communities have different group interpretations of time, according to the cultural heritage of a specific group (Grobler, 1998:50). The average Westerner holds a linear view of time where time is restricted while the traditional African sees time as cyclic and a plentiful source. The inherent conflict that might arise from the expectations that arise from different perceptions and expectations resulting different time conceptions can have negative effects on the mental health of individuals.

In view of the above it was therefore, important to investigate whether the time concepts of high and low achievers differ. Does the mother tongue have any relation to the time concept and the academic achievement of the learners? If there are any differences, what are they and what are the implications of such findings for education and mental health?

\section{QUESTIONNAIRE AND RESEARCH GROUP}

A structured questionnaire in Afrikaans and English was developed according to the above-mentioned time concept by adapting and refining existing instruments. This questionnaire was used to investigate the learners' time concept. Apart from the biographic information, the questionnaire consisted of 39 items about the time concept of an individual.

A purposive sample of 1436 learners from grade eight, ten and twelve were involved. These learners were selected on the basis of the fact that data concerning IQ and other biographical aspects were available. This information was crucial for this research process and that is why random sampling in the case of this study could not be considered. The learners involved were enrolled at Afrikaansmedium (656 students) and English-medium (780 students) secondary schools in the greater Johannesburg area in South Africa.

\section{VALIDITY AND RELIABILITY OF THE IN- STRUMENTS}

The validity and reliability of the measuring instrument were firstly investigated. Item analyses and various consecutive factor analyses consisting of first- and second-order factor analyses were conducted. Analyses concerning reliability were conducted on the time concept scale. From the first order analytical procedure (consisting of a principle component and consecutive principal factor analysis, both with orthogonal axes and varimax rotation) and second order analytical procedure (consisting of a principal factor analysis with orthogonal axes and varimax rotation and a consecutive principal factor analysis with the Doblimin rotation procedure) it followed that single factors for the time concept scale were derived at. The Cronbach alpha score for the time concept scale is 0,738 .

\section{DETERMINATION OF CUT-OFF POINTS FOR TWO GROUPS}

The academic achievements of the group of 1436 learners were rated on a scale from 0 to 100 . The 
median of their scholastic achievement was 57 and this was taken as the line of division between high achievers and low achievers. Further, the group of learners having indexes of 53, 54, 55, 56, $\underline{57}, 58$, 59,60 and 61 was omitted from the research group. This group represents a middle group between high achievers and low achievers.

After eliminating the group between 53 and 61, the original sample of 1436 was reduced to a research group comprising of 1105 pupils: 539 high achievers and 566 low achievers. Thus 316 learners were excluded from further analyses.

\section{VARIABLES (FACTORS) OF TIME CON- CEPT}

The variables (number of factors) of time concept used in the further analysis of the data were identified by means of a factor analysis, together with a Doblimin rotation method. The following variables of time concept were identified: future orientation; conscientious time management; time consciousness; anxiety about the future; present orientation; unconcerned about time; independent utilisation of time; and contentment with present and past. The meaning of each variable is indicated by the questions that were asked, for example:

- Future orientation - to what extent: do you work to fulfil your ideals in the future; are you willing to work hard now, to benefit at a later stage; do you like setting goals for yourself; does your life have a clear goal; are you prepared to work under pressure to achieve success; is it important to you to plan ahead?

- Conscientious time management - to what extent: do you organise your work programme with success; do you know how to utilise time; do you carry out your orders strictly; do you work harder than what is expected of you; are you doing things in order of importance; do you postpone tasks/assignments for today, to tomorrow?
Time consciousness - to what extent: do you experience that time passes quickly; do you regard time as something that passes quickly; do you work fast; is it important to you to know regularly what the time is? Anxiety about the future - to what extent: do you become afraid when you think about the future; does your future look dark, even if you work hard to achieve success; are you being forced by time to do things that you do not want to do; do you experience the days as identical, the one day is only a repetition of the other; do you regard it as useless to remind yourself of things that happened in the past; do you arrive late for school and other gatherings?

Present orientation - to what extent: do you prefer immediate pleasure to working for future success; do you want immediate reaction to your achievements; are you doing only the amount of work which is expected of you; do you ignore the consequences of what you do?

- Unconcerned about time - to what extent: do you enjoy relaxing and forgetting about time; do you find it easy to adapt to new circumstances; do you like enjoying life now irrespective of the consequences?

- Independent utilisation of time - to what extent: do you act independently; do you do important things without being asked or ordered by someone?

- $\quad$ Contentment with present and past - to what extent: do you wish that the present will stay just as it is; do you find it pleasant to think about the past; would you like to change things that happened in the past?

\section{ANALYSIS AND HYPOTHESES}

\section{Differences}

The variables of time concept were used to conduct multivariate and univariate analyses using the 
biographical variables of the learners as independent variables. These analyses were aimed at establishing whether there were any differences between the time concept of high achievers and the time concept of low achievers. In the investigation of these differences in the research group, hypotheses on multivariate and univariate levels were tested. Two sets of hypotheses were tested. When two groups were compared, for example the time concept of high achievers and the time concept of low achievers, the average scale values of the vectors formed were compared with Hotelling's Tsquare test. If a significant difference on the multivariate level was indicated, the differences on the univariate level for each factor were investigated with the Student t-test. The respective hypotheses on multivariate and univariate levels were:

- Multivariate hypothesis (two groups)

$\mathrm{H} \mathrm{T}_{0}$ The vectors of the averages of the two groups do not differ.

H T The vectors of the averages of the two a groups differ.

- Univariate hypothesis (two groups)

$\mathrm{H} \mathrm{t}_{0}$ The averages of the two groups do not differ.

$\mathrm{H} \mathrm{t}$ The average of the first group is higher than a 1 the average of the second group.

$\mathrm{H} \mathrm{t}$ The average of the first group is lower than a 2 the average of the second group.
Significant differences are reported on the $1 \%(* *)$ and $5 \%(*)$ levels of significance.

\section{RESULTS}

The results of the differences between the time concept of the two groups of learners are presented in Table 1. A statistically significant difference $(p=0,000)$ was found between the time concept of high and low achievers. High achievers are more future-orientated, more conscientious in their time management, experience less anxiety about the future, are less focused on the present, utilise their time more independently, and are more contented with the present and the past than low achievers. On the whole, it would therefore appear that two variables of the time concept, namely high anxiety about the future and a present orientation, could cause an inability to achieve academically. Future orientation and conscientious time management indicate goal-directedness, which is one of the characteristics of mental health of a person (Pender, 1987:27). On the other hand, if a person has feelings of anxiety towards the future, defensive reactions may arise (Donald, Lazarus and Lolwana, 1999:293). As a result of this, the person's ability to adjust and to cope with reality is reduced, causing further long-term anxiety that is a concern for educational practitioners.

\section{Table1: Difference between the time concept of the two groups of learners (all learners together)}

\begin{tabular}{|c|c|c|c|c|c|c|c|c|}
\hline \multirow[t]{2}{*}{ VARIABLE } & \multicolumn{2}{|l|}{ N } & \multicolumn{2}{|l|}{-} & \multicolumn{2}{|l|}{$\mathrm{S}$} & \multirow{2}{*}{$\begin{array}{l}\text { Hotelling } \\
\text { p-value }\end{array}$} & \multirow{2}{*}{$\begin{array}{l}\text { Student } \\
\text { p-value }\end{array}$} \\
\hline & $\mathrm{H}$ & $L$ & $\mathrm{H}$ & $\mathrm{L}$ & $\mathrm{H}$ & $L$ & & \\
\hline Future orientation & 539 & 566 & 34,43 & 32,70 & 4,95 & 5,62 & \multirow{8}{*}{0,000} & 0,000 \\
\hline Conscientioustime management & 539 & 566 & 28,11 & 26,89 & 5,92 & 6,16 & & 0,000 \\
\hline Time consciousness & 539 & 566 & 20,61 & 20.45 & 4,03 & 4,15 & & 0,261 \\
\hline Anxiety about the future & 539 & 566 & 21,24 & 23,11 & 6,03 & 6,21 & & 0,000 \\
\hline Present orientation & 539 & 566 & 16,38 & 18,30 & 3,99 & 4,09 & & 0,000 \\
\hline Unconcerned about time & 539 & 566 & 15,14 & 14,87 & 3,07 & 3,61 & & 0,087 \\
\hline Independent utilisation of time & 539 & 566 & 9.92 & 9.67 & 2,17 & 2,47 & & 0,036 \\
\hline Contentment with present and past & 539 & 566 & 10,60 & 10,08 & 3,48 & 3,57 & & 0,007 \\
\hline Number of learners & - & $A_{w}$ & & & & & & \\
\hline Standard deviation & $p-v a$ & & eding pr & bility & & & & \\
\hline High achievers & $\mathrm{L}$ & Lo & achiever & & & & & \\
\hline
\end{tabular}


According to Tables 2a through $\mathrm{c}$, there are more high achievers (328) than low (188) achievers among the Afrikaans-speaking learners. The number of high (175) and low (186) achievers for the English-speaking learners is more or less equal. Among the learners with an African language there are fewer high (28) achievers than low (155) achievers. Afrikaans-speaking high achievers are more time conscious, less unconcerned about time and more independent in the utilisation of time than the low achievers. The Afrikaans- and Englishspeaking high achievers are more future directed, more conscientious in their time management, experience less anxiety about the future and are less focussed on the present and are more content with the present and the past than the low achievers. Although no statistical significant difference were found between the time concept of high and low achievers with an African language, it is important to take notice of the big difference in the number of high (28) achievers and low (155) achievers. This should be of major concern for educators and mental health practitioners.

The differences in the time concept of high and low achievers, as well as the relatively low number of high achievers among learners with an African vernacular, hold some educational implications for learners.

\section{EDUCATIONAL IMPLICATIONS FOR LEARNERS}

In view of the findings that are described above the following recommendations with reference to learners, parents, teachers, are made:

Learners must be assisted to set goals, plan ahead, exchange the pleasure of the present for future success, and to work hard to fulfil

Table 2a: Differences between the time concept of the two groups of learners with Afrikaans as their mother tongue.

\begin{tabular}{|c|c|c|c|c|c|c|c|c|}
\hline \multirow[t]{2}{*}{ УARIABLE } & \multicolumn{2}{|l|}{ W } & \multicolumn{2}{|l|}{ _ } & \multicolumn{2}{|l|}{$\mathrm{S}$} & \multirow{2}{*}{$\begin{array}{l}\text { Hotelling } \\
\text { p-walue }\end{array}$} & \multirow{2}{*}{$\begin{array}{l}\text { Student } \\
\text { p-value }\end{array}$} \\
\hline & $\mathrm{H}$ & $\mathrm{L}$ & $\mathrm{H}$ & $\mathrm{L}$ & $\mathrm{H}$ & $\mathrm{L}$ & & \\
\hline Future orientation & 328 & 188 & 34,91 & 32,13 & 4,54 & 5.17 & \multirow{8}{*}{0,000} & 0,000 \\
\hline Conscientious time management & 328 & 188 & 28.60 & 26.87 & 5.89 & 6.10 & & 0,001 \\
\hline Time consciousness & 328 & 188 & 20.82 & 20.15 & 3,87 & 4,20 & & 0.037 \\
\hline Anxiety about the future & 328 & 188 & 21,69 & 23.61 & 6,03 & 6,23 & & 0,000 \\
\hline Present orientation & 328 & 188 & 16.19 & 17,89 & 3.89 & 3,85 & & 0,000 \\
\hline Unconcemed about time & 328 & 188 & 15.72 & 16,31 & 2,84 & 3.10 & & 0,015 \\
\hline Independent utilisation of time & 328 & 188 & 9.75 & 9,36 & 2,25 & 2,64 & & 0.043 \\
\hline Contentment with present and past & 328 & 188 & 10.87 & 9.97 & 3.61 & 3,70 & & 0,004 \\
\hline Number of leamers & & Awe & & & & & & \\
\hline Standard deviation & p-valu & Exo & gro & lity & & & & \\
\hline High achievers & & 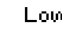 & hievers & & & & & \\
\hline
\end{tabular}

Table 2b: Differences between the time concept of the two groups of learners with English as their mother tongue.

\begin{tabular}{|c|c|c|c|c|c|c|c|c|}
\hline \multirow[t]{2}{*}{ VARIABLE } & \multicolumn{2}{|l|}{ W } & \multicolumn{2}{|l|}{ - } & \multicolumn{2}{|l|}{5} & \multirow{2}{*}{$\begin{array}{c}\text { Hotelling } \\
\text { p-walue }\end{array}$} & \multirow{2}{*}{$\begin{array}{l}\text { Student } \\
\text { p-walue }\end{array}$} \\
\hline & $\mathrm{H}$ & L & $\mathrm{H}$ & L & $\mathrm{H}$ & L & & \\
\hline Future orientation & 175 & 180 & 32.98 & 30.60 & 5,38 & 5.59 & \multirow{8}{*}{0,000} & 0.000 \\
\hline Conscientious time management & 175 & 180 & 26,96 & 24,89 & 5,80 & 5,89 & & 0,000 \\
\hline Time consciousness & 175 & 180 & 19.91 & 19.97 & 4.17 & 4.12 & & 0.445 \\
\hline Anxiety about the future & 175 & 186 & 20,57 & 21,05 & 5,66 & 5.78 & & 0,011 \\
\hline Fresent orientation & 175 & 180 & 16,35 & 17,64 & 3,77 & 4,10 & & 0,001 \\
\hline Unconcerned about time & 175 & 180 & 14,41 & 14,92 & 3,05 & 3.43 & & 0,067 \\
\hline Independent utilisation of time & 175 & 180 & 10.17 & 9.84 & 1,94 & 2,19 & & 0,068 \\
\hline Contentment with present and pat & 175 & 186 & 10,29 & 9.46 & 3,13 & 3,30 & & 0,008 \\
\hline $\begin{array}{ll}\text { N } & \text { Number of learners } \\
6 & \text { Stand ard deviation }\end{array}$ & & Awe & 0 & & & & & \\
\hline High achievers & & Lain & hievers & & & & & \\
\hline
\end{tabular}


Table 2c: Differences between the time concept of the two groups of learners with an African language as their mother tongue

\begin{tabular}{|c|c|c|c|c|c|c|c|c|}
\hline VARIABLE & \multicolumn{2}{|l|}{ N } & \multicolumn{2}{|l|}{ - } & \multicolumn{2}{|l|}{$\mathrm{S}$} & $\begin{array}{l}\text { Hotelling } \\
\text { p-value }\end{array}$ & $\begin{array}{l}\text { Student } \\
\text { p-value }\end{array}$ \\
\hline Future orientation & 28 & 155 & 37,25 & 35,68 & 3,60 & 4,61 & \multirow{4}{*}{0,088} & 0,025 \\
\hline Anxiety about the future & 28 & 155 & 22,36 & 23,93 & 7,59 & 6,42 & & 0.124 \\
\hline Present orientation & 28 & 155 & 19.57 & 19,53 & 3,88 & 4,00 & & 0.479 \\
\hline Unconcemed about time & 28 & 155 & 13,00 & 13,48 & 3,85 & 3,72 & & 0,268 \\
\hline N Number of learners & & Awe & & & & & & \\
\hline Standard deviation & $\bar{p}$-valu & Exo & ing prot & lity & & & & \\
\hline
\end{tabular}

their ideals in the future.

Learners should be assisted to help people to organise their available time and guide them to utilise their time purposefully: this includes aspects such as organising their work programme with success and carrying out their orders strictly.

Educators should create a supportive environment where learners can look forward to the future with confidence and to realise that hard work will be rewarded with success.

Educators should provide specialised attention and training for learners with an African vernacular. These learners should be sensitised towards development of a linear and integrated time concept. In this regard time should be viewed as scarce resource and valued as such. This should then be characterised by the ability to set goals, to plan ahead, to exchange the pleasure of the present for future success, and to work hard to fulfil their ideals in the future.

It should therefore be in the interest of learners if educators make every effort to foster a future oriented time concept in them. The emphasis should be placed on planning and working towards future goals. In addition, it should be stressed that the enjoyment of the moment should be exchanged for future success. Further research needs to be done to find ways and means to change learner's time concept in order to cope with expectations and actualise their full potential.

\section{REFERENCES}

BEN-BARUCH, E 1985: Conception of time, theoretical framework and some implications for education. (In: Ben-Baruch, E \& Netmann, Y eds. 1985: Studies in education administration and policy making. Herzalia, Israel: Ben Gurion University of the Negev).

BEN-BARUCH, E; MYBURGH, CPH; WIID, AJB \& ANDERSSEN, EC 1990a: Differential time perception of a group of American adolescents - a study utilizing projective tests. [In: Myburgh, CPH 1990: Instrument development for measuring time perception (Ad hoc-investigation).] Pretoria: HSRC.

BURGERS, HH 1993: Tydpersepsie as faktor in produktiwiteitsopvoeding. Johannesburg: Randse Afrikaanse Universiteit. (DEd-proefskrif).

DONALD, D; LAZARUS, S \& LOLWANA, P 1999: 
Educational Psychology in social context. New York: Oxford University Press.

GORMANN, BS \& WESSMAN, AE 1977: The personal experience of time. New York: Plenum

Press.

GROBLER, RC 1996: Selfkonsep, tydkonsep en skolastiese prestasie. Johannesburg: Randse

Afrikaanse Universiteit (DEd-proefskrif).

GROBLER, RC; MYBURGH, CPH \& KOK, JC 1998: Selfkonsep, Tydkonsep en skolastiese prestasie. SuidAfrikaanse tydskrif vir Opvoedkunde, 18(1), 1998:4957.

GMEINER, AG \& POGGENPOEL, M 1997: Riglyne vir " $n$ omvattende verrykingsprogram vir die bevordering van die geestesgesondheid van onafhanklike sakemanne.

Health SA Gesondheid, 2(2), 1997:10-15.

GROSS, E; NOLTE, A \& SMITH, D 1996: Gesondheid: 'n realistiese perspektief. Health SA Gesondheid, 1(1), 1996:3-8.

JAQUES, E 1982: The form of time. New York: Crane Russak.

MARAIS, JL (ed.) 1999: Practice of school guidance. Unpublished study guide. Potchefstroom: PU.

MBITI, J 1967: The African concept of time. (In: Rauchfuss A \& Splett, O eds. 1967: Africa

German Teview of political economic and cultural affairs in Africa and Madagascar. Ilmgaudrucherei: Pfaffenhofgen.)

MYBURGH, CPH; GROBLER, RC \& NIEHAUS, L 1999: Predictors of scholastic achievement: IQ, selfconcept, time concept and background characteristics. South African Journal of Education, 19(3), 1999:165178 .

PENDER, NJ 1987: Health promotion in nursing practice. California: Appleton \& Lange. 